\title{
Selected E-Course Controls: Accounting Department Heads' Views
}

Gary Saunders (Email: saunderg@marshall.edu), Marshall University Jean Price (Email: price91@marshall.edu), Marshall University

\begin{abstract}
Use of the Internet continues to increase, and new technology continues to provide more and better communication options. As more and more students choose to enroll in Internet courses (e-courses), technological advances offer various ways to control academic dishonesty. A questionnaire was developed and distributed to chairpersons of accounting departments to obtain their views about the use of several technological enhancements that could serve as controls in e-courses. Such controls would require that some of these newer physical enhancements be on students' computers when they register for an e-course. Respondents strongly favored requiring students to provide a digital photo ID and audio capabilities when registering for an e-course. Other potential controls were not supported. Those surveyed also tended to believe that students should use a web cam when completing examinations on-line and that faculty should compare the photo ID with the web cam image. In other settings, they felt that such a comparison was unnecessary. Overall, the accounting department heads surveyed endorsed requiring the student who enrolls in an e-course to obtain some existing technology, and they expect the student to be prepared to spend more than $\$ 100$ to obtain the technology.
\end{abstract}

\section{INTRODUCTION}

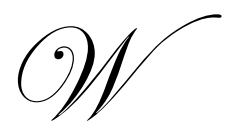

hen electronic courses (e-courses) were first developed, some thought they were just a passing fad, and others took action to explore new possibilities. Discussions among educators in various fields arose, and many of the issues continue to be a source of debate. Accounting educators were no exception - they, too, evaluated the pros and cons of this new delivery method. Among the questions raised were: Will e-courses maintain the level of rigor inherent in the traditional course offerings? Will students be disadvantaged by foregoing the typical classroom interaction? Will students taking an e-course feel as comfortable asking questions of the teacher? Will all of the explanations traditionally enhanced by the use of blackboards (or white boards) be lost in translation?

Many concerns about e-courses were voiced. In most cases, faculty opinions about such issues varied widely. One concern, however, seemed to be held by all: Will teachers be able to prevent academic dishonesty in e-courses to the same degree that they had controlled it in the traditional setting? Eisenberg (1999) suggests that eliminating cheating on exams administered in Internet courses is not possible without face-to-face proctors. He does concede, however, that use of some electronic tools, while possibly not a very cost effective approach, can help mitigate the problem. When first widely offered during the 1990 s, e-courses may have seemed like a ripe opportunity for students to cheat. Since then, a variety of controls intended to address this issue have been developed. Some are incorporated within software used in the-course; others are built into the very structure of the-course itself. Some controls are based on procedures that must be performed by the professor and others are simply automatic.

In spite of the use of such controls, however, faculty perceptions of control in e-courses suggest that the problem has not yet been resolved. Survey results from one recent study indicate that more than $60 \%$ of accounting chairpersons perceive the instructor's level of control in an e-course to be considerably less than the level in a traditional course (Saunders, 2002). 


\section{BACKGROUND}

During the decade of the 1990s, developments in technology offered a new delivery vehicle for distance learning courses. With the rapid spread of the Internet and e-mail, time and space constraints ceased to be a problem. Students and instructors could engage in the learning process in real time without the cumbersome television connections and other paraphernalia required by earlier distance learning methods. Over the Internet, a student anywhere in the world who had a computer and an Internet connection could now complete an Internet course and communicate with his or her instructor. New jargon was needed to describe the new environment so terms like "Internet courses," a.k.a. "e-courses," "chat rooms," and "e-mail" were added to the academic lexicon. In the past decade, e-courses, "the new kids on the block," have experienced phenomenal growth and they appear to be poised to compete with traditional, on-campus courses for students' tuition. Many universities seem to sense a source of previously untapped revenue, offering courses to anyone in the world who has a computer and an Internet connection.

\section{Growth and Difficulties of E-Courses}

E-courses represent an even greater departure from the traditional learning model than either correspondence or ITV courses did. In a survey of accounting chairpersons, Saunders (2002) found that by more than a 9 to 1 margin, accounting chairpersons believe that the level of control an instructor possesses with Internet courses is substantially less than that in traditional courses. Uncertainty over who is actually completing the assignments in e-courses is of concern to most, with $68.3 \%$ saying they are less certain than with traditional courses. Apparently, control is an issue of concern with accounting chairpersons and, one would expect, with other administrators and faculty as well.

Many of the traditional controls available with other types of distance learning courses are not as easily implemented with e-courses. Proctoring of exams has been the norm with other methods, but with e-courses, proctoring may be more difficult and appears to be demanded less often by administrators. One real advantage of Internet courses is bringing education to persons in extremely remote locations, and this poses problems in locating suitable proctors. Traditionally, proctors have been credentialed educators who were unbiased with respect to the student. In population centers, this type of proctor is not too difficult to locate but in the frozen tundra of Alaska or the sweltering outback of Australia, finding one may be impossible. In effect, when a university offers an Internet course with no required campus visits and no proctors for the exams, it gives up virtually all of the traditional controls over the-course and accepts on faith that the student receiving credit for the-course is the same person who completes the assignments.

Given the challenges that Internet courses present, one might expect that colleges and universities would proceed cautiously and test carefully before implementing Internet courses and degree programs. To the contrary, however, they have activated courses and programs at a surprising rate. The 1993 Peterson's College Guide listed 93 "cyberschools" and the 1997 Distance Learning Guide listed 762. That represents a phenomenal growth of more than 700 percent. Vasarhelyi and Graham [1997, p. 32] state that "In the last two years, the emergence of the Internet has opened the doors for a permanent revolution in the classroom and educational processes. ... About $55 \%$ of America's 2,215 colleges and universities have-courses available off site." By 1998, more than 1,600 institutions were offering about 54,000 e-courses with 1.6 million students enrolled. Forbes reported that "in December 1999, the National Center for Educational Statistics (NCES) of the U.S. Department of Education (USDE) released a national survey on what it calls "distance learning" in higher education. In 1997-98, almost $44 \%$ of all higher education institutions offered distance courses. Larger institutions are moving fastest; $87 \%$ of those with more than 10,000 students offered distance classes, while only $19 \%$ of institutions with fewer than 3,000 students did so. Total enrollment in postsecondary, credit-granting distance learning courses in 1997-98 was 1,363,670; the number has grown considerably since, although as yet there are no firm figures" [Forbes, 2000]. The American Federation of Teachers indicated that "distance education is one of the fastest-growing developments in higher education. Seventy percent of the nation's 4,000 two-and four-year colleges offered online-courses in 2000, up from 48 percent in 1998" [Black Issues in Higher Education, 2001].

The 2004 Sloan Survey of Online Learning reported that about 2.6 million U.S. college students are taking courses online this fall and enrollments in such courses are rising at rates faster than overall college enrollment. The term "business" would seem appropriate because, in addition to traditional nonprofit universities, many for profit 
businesses have sprung up to take advantage of the money making potential offered by the growth in distance learning. One website [http://www.collegeathome.com/] boasts that it can show you "over 500 U.S. Universities and Colleges, all fully accredited, offering online degrees in over 900 different fields (over 10,000 different programs offered) from Bachelor's to Doctorate's." The website goes on to list some of the most highly respected universities in the U.S. Add to that the large number of colleges and universities that are not accredited and the more than 1,600 corporate universities [e-learning, www.elearningmag.com, October, 2001] offering Internet courses and the growth in Internet course offerings is astounding.

\section{THE STUDY}

Internet courses represent an even greater departure from the traditional learning model than previously available distance learning methodologies. Proctoring of exams has been the norm with previous methods of delivering distance learning courses but with Internet courses proctoring becomes much more difficult and appears to be demanded less often by administrators. As mentioned, control is an area of concern for accounting chairpersons and uncertainty over who is actually completing the assignments in e-courses is troublesome.

Accounting department chairpersons typically participate in the development of Internet courses and the control features incorporated in the administrative procedures. In order to obtain the opinions held by accounting chairpersons regarding the use of some of the available electronic tools for controlling academic dishonesty in Internet courses, a questionnaire was developed and e-mailed to 471 chairpersons of accounting departments at universities and colleges in the U.S. Of the 471 mailed, 69 were undeliverable because of addressing problems leaving 402 delivered questionnaires. A total of 56 responses (14\%) were received. Statements in the questionnaire related to technological controls that are currently available, application of those controls in administering e-courses, as well as information about the respondents' schools, and their personal experience with online-courses.

\section{RESULTS}

Questionnaires were sent via e-mail and three different response modes were offered. If respondents were concerned about anonymity, it was suggested that they either: (1) print the questionnaire, complete it, and mail it to the author, or (2) click on an Internet address and complete a web page version. Both of these response methods would help insure anonymity. The third method of responding was to choose "reply" in their e-mail program, complete the questionnaire, and click on "send." Responses began arriving within hours of the initial mailing.

\section{Offering and Teaching E-Courses}

Two statements referred to whether the respondent's college or university offered e-courses and whether the respondent had actually taught an e-course. As shown in Figure 1, 74.5\% of the schools offer e-courses and 29.1\% of the respondents have taught a course on the Internet. Results of a study completed about two years ago indicate that about the same portion of schools ( $75 \%$ ) offered e-courses, but the percentage of respondents who had actually taught an e-course was only $12.2 \%$. Those data may suggest that the number of e-courses offered in accounting is increasing.

\section{Online Identity Verification Controls}

The survey included a series of statements related to the use of physical controls, such as digital photos for identification, using web cams, and the use of audio capabilities. For each control measure, respondents were asked whether the control should be used and then, if it is currently being used at their schools. Statements relating to whether the control measures should be used offered five response options ranging from "strongly disagree" to "strongly agree." For presentation of the results, the two "agree" response categories were combined into one, as were the two "disagree" categories. Items asking about the current use of each control provided three responses: "yes," "no," and "don't know."

Data in Figure 2 indicate that only $6 \%$ of the respondents objected to requiring students to provide a digital photo when registering for an e-course, while more than $66 \%$ thought that it should be used. Such a photo could be used for confirming the identity of the student in a variety of settings. Providing a digital photograph is relatively inexpensive 


\section{Offering Courses \& Teaching Courses}

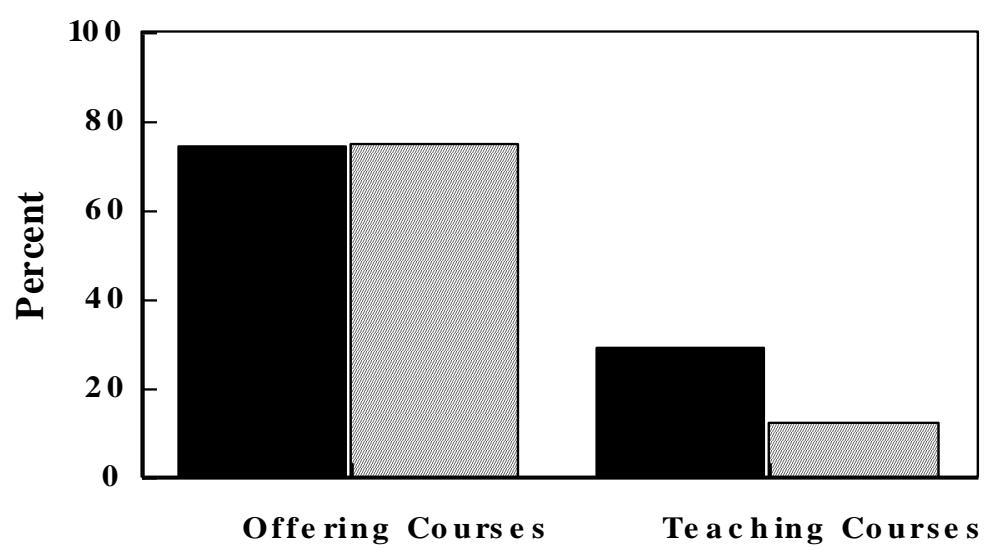

Figure 1

\section{Students Should be Required to Provide a D igital Photo When Registering for an E Course}

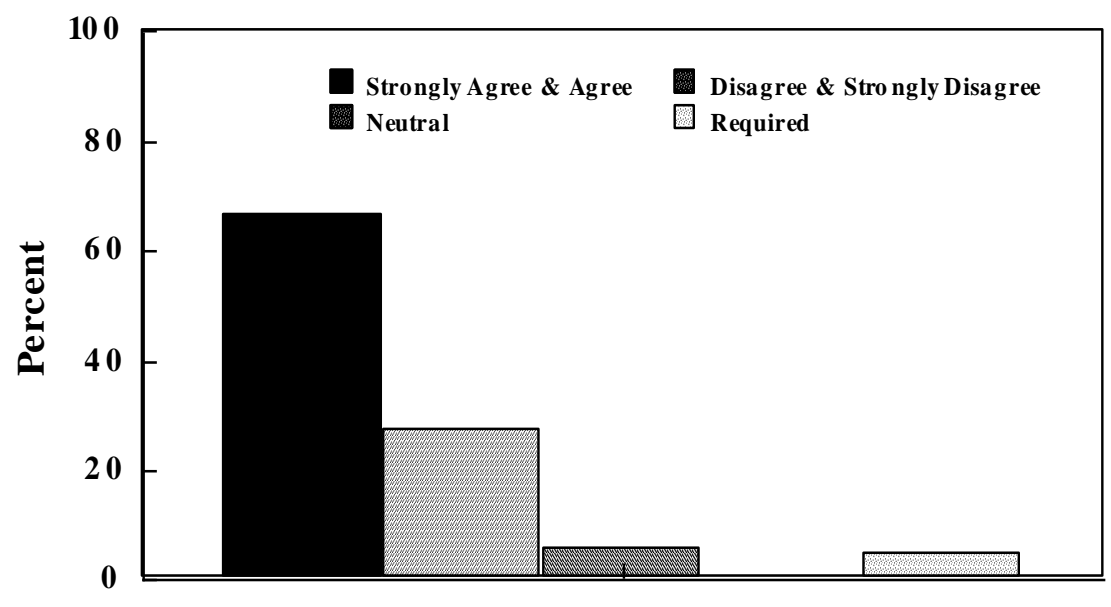

Figure 2

and that may be a factor in the recommendation by two-thirds of the accounting chairpersons that it be used. Unfortunately, as illustrated in Figure 2, less than 5\% of the schools in the study actually require a digital photograph to be provided when a student registers for an e-course.

As seen in Figure 3, slightly more than 35\% of the respondents disagreed with requiring a student to obtain a web cam when registering for an e-course. However, that leaves almost two-thirds, more than $25 \%$ agreeing and nearly $40 \%$ neutral, who did not object to the requirement. The perceived cost of a web cam may have influenced those who objected. None of the respondents indicated that their schools required students to obtain a web cam in order to register for an e-course. 
Stude nts Should be Required to Provide a Web

Cam When Registe ring for an E Course

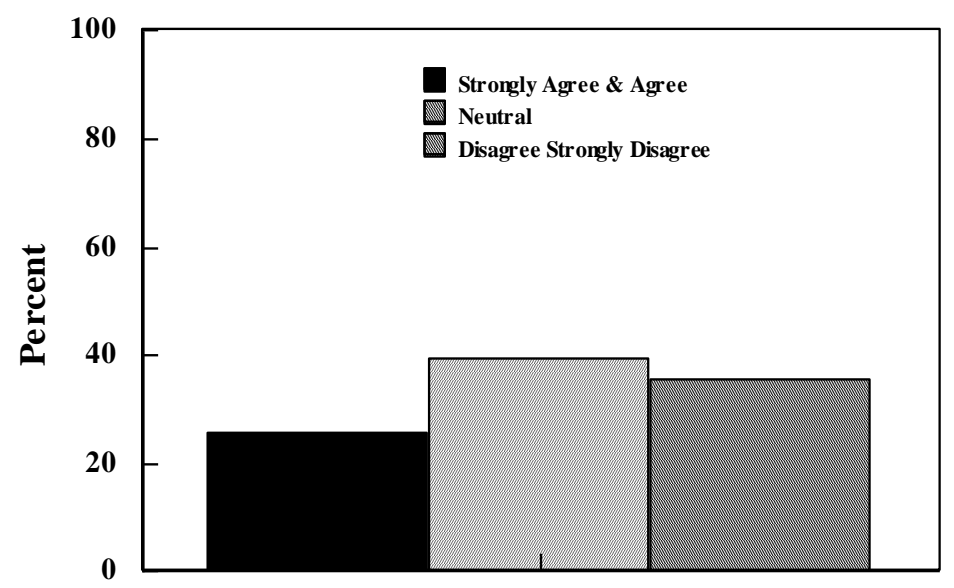

Figure 3

Students Should be Re quired to Obtain Audio Capabilities When Registering for an E Course

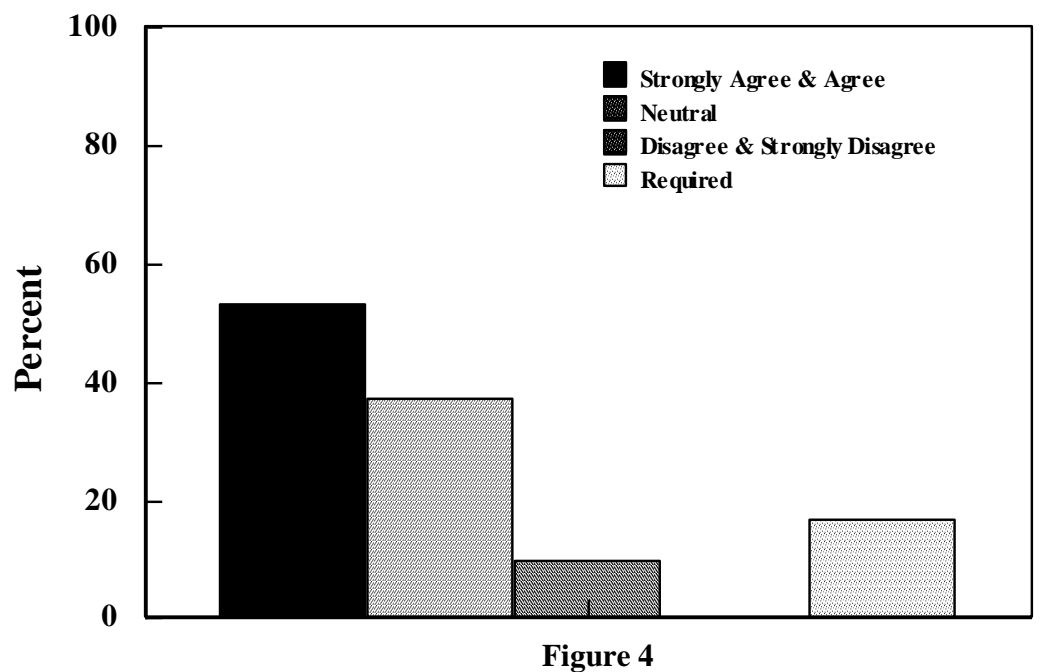

Another statement considered requiring the student to obtain audio capabilities when registering for an e-course. Audio capabilities would not only serve to improve control, but would also make student-instructor communication much more productive. As shown in Figure 4, 53\% agreed or strongly agreed that students should be required to obtain audio capabilities when registering for an e-course. Only 10\% disagreed. Almost $17 \%$ of those surveyed indicated that their school required students to obtain audio capabilities.

A related statement on the survey asked about the amount of money students should be prepared to spend for upgrades on their computers "in order to obtain the 'desired technology' for completing an e-course." Respondents were presented five monetary options, ranging from "up to $\$ 50$ " to "more than $\$ 150$." As the response percentages in 
Figure 5 indicate, very few of the department heads chose the lower categories. Almost $40 \%$ indicated that students should be prepared to spend more than $\$ 150$ to upgrade their computers for an e-course. Another $40 \%$ chose one of the next two categories, indicating that students should be prepared to spend between $\$ 75$ and $\$ 150$ for any required upgrades. Clearly, the overwhelming majority of respondents expect students to be prepared to invest more than $\$ 75$ to upgrade their computers for an e-course. That amount would cover the cost of a web cam and audio capabilities; the failure of a larger percentage to recommend requiring a web cam suggests that many respondents may be unaware of the low cost of these upgrades. The question related to spending dollars was purposely placed after the items asking for reactions to proposed use of each physical control. Such arrangement was intended to limit the impact of the cost factor as the respondents considered each potential control.

\section{The Amount of Mone y Students Should be Prepared to Spend to Upgrade Their Computer for an E Course}

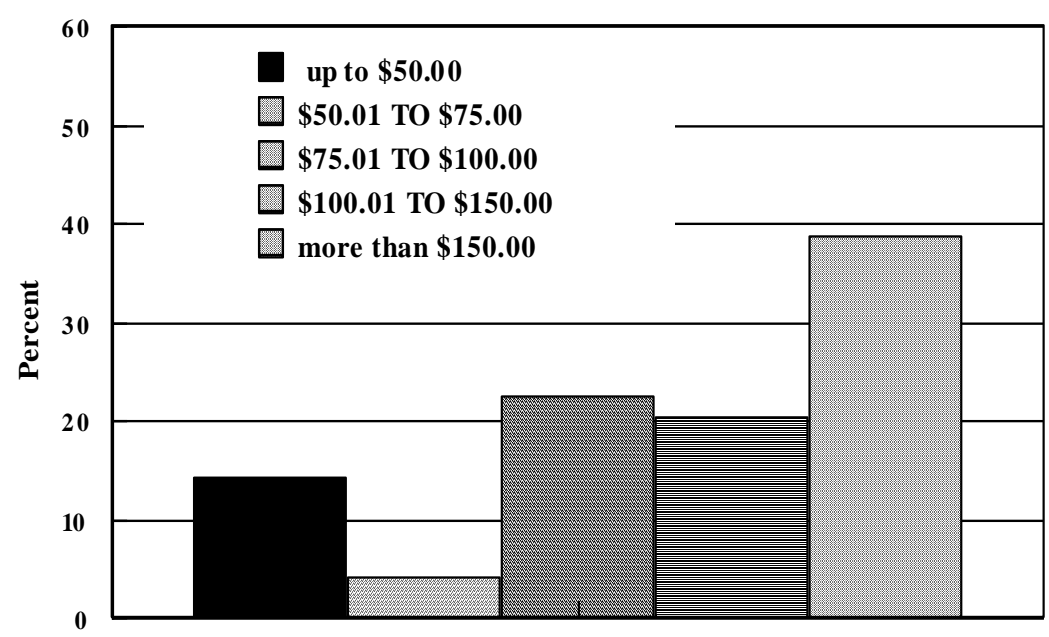

Figure 5

Without controls, the possibility exists that the student registered for the-course is not the student actually completing the-course work. The department heads were asked to react to proposals that faculty use photo ID's and web cams in three different settings. The first of these statements said, "Faculty should compare images from a photo ID with the 'web cam' image when monitoring examinations completed on-line to insure that the student registered is actually completing the examination." As shown in Figure 6, almost half (45.8\%) of the respondents agreed with the statement while only $20.8 \%$ disagreed. With about $80 \%$ not objecting to the use of digital photo IDs as a control measure when monitoring on-line examinations, the measure appears to be an acceptable method of insuring that the student taking the exam is the same student who registered for the-course. Respondents indicated that none of their schools actually require faculty to compare a photo ID image with a web cam image when students were completing examinations online.

The potential for a "stand-in" to complete homework assignments on-line also exists. One proposal said, "Faculty should compare images from a photo ID with the 'web cam' image when monitoring homework assignments completed on-line to insure that the student registered is actually completing the assignment." As seen in Figure 7, only $21.3 \%$ agreed and nearly half (48.9\%) disagreed. None of the respondents indicated that faculty at their schools are actually required to compare a photo ID image with a web cam image when students are completing homework assignments online. Perhaps accounting chairs do not believe that homework assignments are important enough factors in the grading process to motivate employing the use of a surrogate to complete the assignment or to use control measures to insure the identity of the person completing the assignments. 
Faculty Should Compare Image s From a Photo ID With the Web Cam Image Whe n Monitoring Examinations Comple te d On-Line

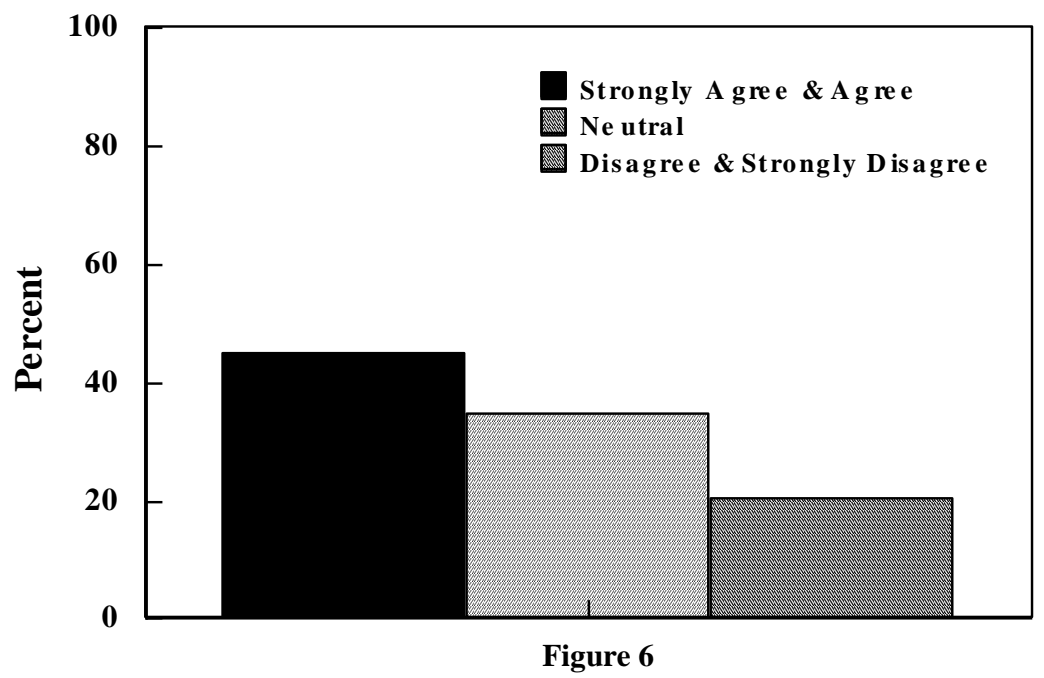

Faculty Should Compare Image s From a Photo ID

With the Web Cam Image When Monitoring

Home work Assignme nts Comple te d On-Line

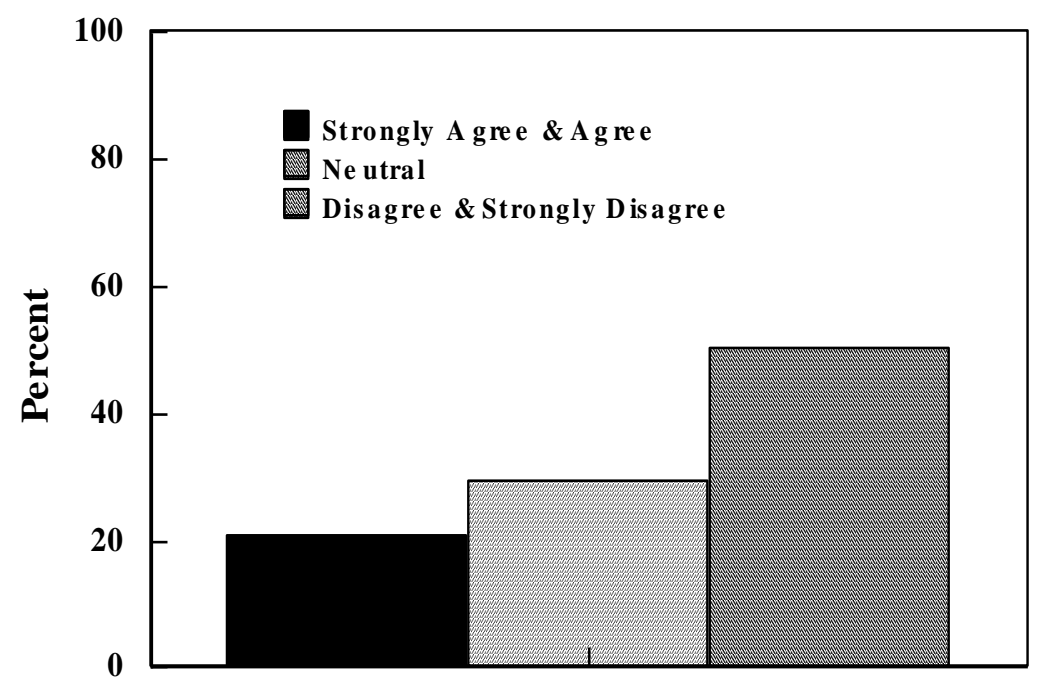

Figure 7

The third statement pertaining to the use of a web cam proposed, "Faculty should compare images from a photo ID with the 'web cam' image when conducting on-line 'chat' rooms to insure that the student registered is actually participating in the "chat' room." As seen in Figure 8, fewer than $20 \%$ of the respondents supported the suggestion of comparing images from a photo ID with a web cam image to verify that a student participating in a chat room discussion was the same student registered for the e-course. Nearly half (43.75\%) disagreed with the idea, and $37.5 \%$ were neutral. 
As in the setting of homework completion, respondents do not strongly endorse the use of a web cam in chat rooms; no schools included in the survey actually require such a control in e-courses.

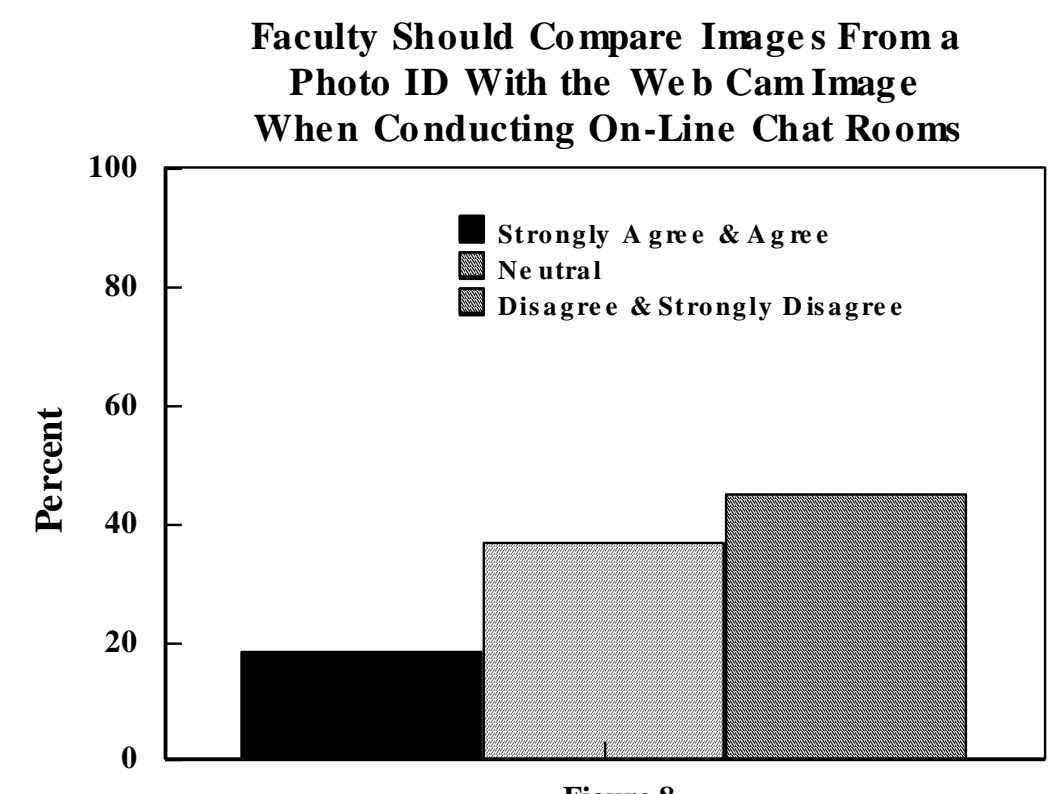

Figure 8

\section{Sample Characteristics}

Response data indicates that the typical respondent is chairperson of an accounting department in a public university with a total FTE enrollment of about 10,000 students. The college of business has slightly more than 1,000 FTE students and about 200 of them are majoring in accounting. In more than three-fourths of the schools the college of business is accredited by the AACSB and almost half of the accounting programs are accredited with most being accredited by the AACSB. The typical school offers an MBA and half offer a Masters in Accounting.

\section{CONCLUSIONS}

The growth of e-courses and Internet degrees continues unabated, and some sources place the number of institutions offering on-line degree in the 1,100 range and the number of degree programs at about 3,500. E-courses represent a major departure from the traditional teaching model because the student and the instructor may be separated by both time and distance. Some technological enhancements that can help bridge the time and distance gulf are now available.

Responses to a questionnaire distributed to chairpersons of accounting departments in the U.S. relating to the use of some of these devices indicated that respondents strongly favored requiring students to provide a digital photo ID and audio capabilities when registering for an e-course. However, they rejected the idea of requiring students to provide a web cam that might be used for verifying their identity. Accounting chairs indicated that a student registering for an e-course should be prepared to spend more than $\$ 100$ to upgrade their computer.

Respondents also tended to believe, even though they did not endorse requiring one, that students should use a web cam when completing examinations on-line and that faculty should compare the photo ID with the web cam image. However, they do not believe that students should be required to use a web cam when completing homework assignments or that faculty should compare the photo ID with the web cam image. Additionally, the department heads felt the comparison of a photo ID with a web cam image when students participate in on-line chat rooms was not seen as necessary. 
As technological innovations are developed, the control over academic dishonesty in E-courses may be improved. Education delivered over the Internet is already widely offered; but, as of now, accounting educators are divided on exactly which of the available control devices should be implemented consistently in these classes.

\section{REFERENCES}

1. “Accredited College Degrees by Correspondence," http://www.collegeathome.com/, 2002.

2. Banas, Edward J. and Emory, W. Frances, "History and Issues of Distance Learning", Public Administration Quarterly, p. 365-383, Vol. 22, Issue 3.

3. Bertagnoli, Lisa, "Education Reservation”, Marketing News, Vol. 35, Issue 4, February 12, 2001.

4. Carnevale, Dan, "Turning Traditional Courses Into Distance Education", Chronicle of Higher Education, Vol. 46, Issue 48, August 4, 2000, p A37-9.

5. Carr, Sarah, "A University Moves to Require Distance-courses", Chronicle of Higher Education, Vol. 47, Issue 8, October 20, 2000, p A48.

6. Deakin, Michelle Bates, "The Failings of Distance Learning", Computerworld, Vol. 35, Issue 5, 2001.

7. "elearning", http://www.elearningmag.com, October, 2001.

8. $\quad$ Eisenberg, Daniel, "Cheating in the Virtual University", Virtual University Journal, February, 1999.

9. Gaskin, James E. \& Calera, Robert E., "Virtual Learning Struggling to Make the Grade”, Inter@active Week, Vol. 7, Issue 4, August 28, 2000, p 28-9.

10. Hagen, A. \& Omolayole, O., "The Impact of Technology Mediated Distance Learning on American Business Colleges: an Empirical Investigation", Proceedings of the OOICTL-Business 2000 International Conference, p. 143-6, September, 2000, Shreveport, LA.

11. Hereford, Lady, "Virtually No Consistency in Online College-courses", Community College Week, Vol. 12, Issue 15, March 6, 2000, p 8-9.

12. McCartney, L., "Virtual MBA -- Going Back to School Doesn=t Have to Mean Sitting in a Classroom Again", Informationweek, November, 1996, p 32-36.

13. "New AFT Report Proposes Standards for Online Programs", Black Issues in Higher Education Vol. 17, Issue 5, February 1, 2001, p. 43.

14. Noam, E. M., "Electronics and the Dim Future of the University", American Society for Information Science, Bulletin of the American Society for Information Science, 22(5), 1996, p 6-11.

15. Oblinger, Diana \& Kidwell, Jill, "Distance Learning Are We Being Realistic?" Educause Review, Vol. 35, Issue 3, May/June 2000, p 30-37.

16. Oppermann, O., "E-mail Surveys - Potentials and Pitfalls", Marketing Research, 7(3), 1995, p 29-33.

17. Roach, Ronald, "The Army Marches Into Online Learning", Black Issues in Higher Education Vol. 17, Issue 24, January 18, 2001, p. 32-3.

18. Schank, Roger C., "The Virtual University," CyberPsychology \& Behavior, Vol. 3, Number 1, 2000.

19. Schuldt, B. A., \& Totten, J. W., "Electronic Mail Vs. Mail Survey Response Rates", Marketing Research, 6(1), 1994, p 36-41.

20. Saunders, Gary, "A Comparative Analysis of Distance Learning Delivery Methodologies", presented to the 9th IAAER World Congress of Accounting Educators, Hong Kong, China, November, 2002.

21. Smith, W., "The Advantages and Disadvantages of Online Delivery of Accounting Courses: Pitfalls to Avoid", presented at the Fiftieth International Economics Conference, October, 2000, Charleston, SC.

22. Svetcov, Danielle, “The Virtual Classroom vs. the Real One”, Forbes, Vol. 166, Issue 7, p. 50-52, September $11,2000$.

23. Trotter, Andrew, “Online Education”, Education Week, Vol. 24, Issue 13, p. 16, November 24, 2004.

24. Vasarhelyi, M. A., \& Graham, L., "Cybersmart: Education and the Internet", Management Accounting, August, 1997, p 32-36.

25. Vazzana, G., \& Bachmann, D., "Fax Attracts", Marketing Research, 6(2), 1994, p 18-25. 
NOTES 